\title{
The Study on Strengthening the Practicing Link of the Teaching of the Equipment
}

\author{
Jiang Wei, Li Ning, Chen Zhi-ling, Hua Peng-xiang and Chen Liang-ming \\ Wuhan Mechanical Technology College \\ Wuhan, Hubei Province, China \\ jw007305@126.com
}

Keywords: buffer braking device; disassembly and assembly; hydraulic control

\begin{abstract}
In recent years, unit quantity, higher quality equipment, in order to rapidly form a new maintenance support ability of equipment, equipment must be strengthened in the teaching practice. To better prepare the practical link in teaching first to strengthen the structure and principle of the teaching, and lay the solid foundation trainee maintenance. Secondly, improvement of teaching methods and teaching support should be synchronized to keep up and strengthen students ' ability of equipment maintenance training and fault diagnosis of exclusion. Only close to the troops, closer to the equipment, close to secure to become innovative and high-quality military personnel of a new type of work skills.
\end{abstract}

\section{Strengthen the meaning of the teaching practice of the equipment}

With more and more new equipment to the armed forces, the need to quickly forming a new equipment maintenance support capability, teaching equipment, especially the practice of teaching is to foster sergeant students' ability of equipment support, use and maintenance of important link, is an effective method for the position need. Therefore, we must strengthen the equipment in teaching practice $^{[1]}$.

1. Do the laws of education. Served the purpose of education is to make the sergeant students meet the needs of the position, develop their professional quality, complementary and widen their knowledge and ability, as soon as possible into the job role compared with record of formal schooling education, as education in the training target, teaching content, teaching methods, teaching means and choice, we must stick to the position requirement oriented, and to standardize the process of education and teaching behavior, in the teaching practice ${ }^{[2]}$.

2. Meet the demand for talent forces development. Record of formal schooling education is needed in order to develop our army modernization construction theory, applied and other kinds of military personnel, theoretical foundation and application in education and knowledge.

With the deepening of the force transformation of construction, the demand for talent is increasing day by day, requires colleges to cultivate talents to adapt to the forces the position of cycle as short as possible. According to the requirements of the office, dedicated to a specific military post applied talents, makes every effort to make the educates to get much-needed knowledge as soon as possible, so as to adapt to the need of modern war and post work ${ }^{[3]}$.

Adhere to the theory with practice, in view of the new knowledge, new theories, new methods, new technology, new teaching and training skills, emphasize the practicability of teaching content and practice, adhere to is consistent, the education training closely combining the actual requirement of working, it needs more practice in the teaching equipment.

3. Improve the need of sergeant student's comprehensive quality. The teaching of practice is to cultivate the sergeant student's practical ability and creation ability, an important channel, relative to the theoretical teaching, practical teaching more objective, comprehensive and innovative features. Through teaching practice, not only can make sergeant students operation ability, practical ability and creative ability of ascension, but also help temper to be practical and realistic, down-to-earth style of work, accumulated certain experience, cultivate the spirit of collaboration with people and social experience, make oneself more close to the real society and work ${ }^{[4]}$. 


\section{Strengthen the teaching practice of the equipment}

1. The practice link of teaching equipment to strengthen equipment principle knowledge teaching. Mastering the basic knowledge of equipment maintenance necessary is the precondition of exclusion of equipment failure, including the knowledge structure, working principle, technical equipment operation method to solve the problems, the order of the steps and troubleshooting, etc. All the basic knowledge, the structure and working principle of equipment is particularly important, is the foundation of equipment maintenance. The foundations of strong or not directly affects the improvement of equipment maintenance support capability. Equipment maintenance in the teaching of the educational reform in recent years, due to an increase in the number of equipment, each of the equipment class time decreased. In the case of less class hour, in order to achieve good teaching effect of maintenance, repair parts have sufficient guarantee practice, and further compression of equipment structure theory class teaching classes; Furthermore, with the development of science and technology, equipment structure and the principle of more and more complex, covering machine, electric, magnetic, mechanical and fluid, and many other professional disciplines, equipment structure and principle of the teaching should have sufficient teaching time. Currently equipped in teaching "equipment increasing, compression teaching time, ensure maintenance effect, compression structure school" approach, is actually a kind of vicious circle, causes the structure principle foundation is not solid, such as maintenance ability couldn't get on. Maintenance practice teaching no increase but not foundation of class can improve students' ability of analysis of equipment fault judgment ${ }^{[5]}$.

Therefore, along with the quantity, the quality of the equipment to promote, structure and principle of teaching classes should be increased, the foundations of the prison students and equipment maintenance. Of course, on the basis of the guarantee structure under the premise of teaching hours, teaching method improvement, the improvement of teaching methods and teaching guarantee the increase of the related measures should be kept pace. Basis of comprehensive reform, to play equipment knowledge, further enhance the analysis of equipment fault judgment.

2. The practice link of teaching equipment, equipment maintenance skills training must be strengthened. Equipment maintenance of the basic skills of content is very wide, both maintenance tools for the proper use of equipment, selection and implementation of the repair process, the safety of the operation, etc., also covers "cars, pliers, welding and other metal machining knowledge. In equipment maintenance in the teaching process, because the time is limited, very few students for specialized basic skills training, the teaching content of which is neglected for a long time.

Equipment maintenance support work, however, it is composed of many basic skills unit, namely the sum total of the unit basic skills proficiency is equal to the speed of the equipment maintenance. Fault judgment is right, while the fault locations are found, but due to the poor basic skills in limited time cannot be completely ruled out the fault. Therefore, to master basic skills is very important for equipment maintenance support. To cultivate professional students' basic skills of maintenance, the equipment maintenance practice, the reform of the course should increase the related technical operation, especially in the form of homework assignments, let students make full use of the self-study time according to oneself circumstance selectively for training. Basic skills practice repeating monotonous, can take the team competition, exchange of experience and regular evaluation of flexible and varied forms, overcome in the process of training students' boredom. For the core and main components of equipment, can be used as part of a commission co-chaired arrangement in advance, clear the inspection requirements and scoring criteria, the final purpose is to speed and maintenance quality inspection skills. Self-study time for students to provide the corresponding equipment and tools, let students practice independently, both to strengthen the skills training, and do not take up un-con teaching time, can achieve twice the result with half the effort ${ }^{[6]}$.

3. The practice link of teaching equipment to increase the content of equipment. Equipment is usually used in teaching performance fully intact or basic equipment, set of failure is failure. Man-made fault and the actual fault phenomena and fault parts have great differences. For as much as possible close to the reality, the type of fault should be multiple faults in the equipment to be used in training and maintenance. Such fault is divided into two categories: one is naturally formed 
fault, such as wire connector long-term corrosion lead to break the natural fault, can use transparent tape again after received the plug wire surrounded the thread hole were simulated, loose parts bolt in natural fault in the part of the bolt to simulate in unloaded and release mechanism; It is setting error fault maintenance, equipment in the process of normal maintenance, due to the maintenance personnel error, make the adjustment of components or assemblies loses or installation dislocation caused by the fault, although this kind of failure only occur in just finished maintenance of equipment or new equipment, but also more see. Set fault is to test students' ability of comprehensive analysis, judgment and problem solving, examination should focus more on the equipment basic knowledge and basic skills assessment. Basic jobs, to improve students' ability of analysis of equipment fault judgment. Fault Settings should reflect the basic knowledge of the basic skills of inspection and appraisal. Students of fault judgment must be applied equipment, for example, the structure and principle, and so on the basis of knowledge, in the process of troubleshooting must master the skills related to operation, etc. Therefore, in the practice link of teaching equipment to increase the content of equipment fault diagnosis is very necessary.

4. The practice link of teaching equipment to increase the colleges and universities and the army training content. Served in the make the students grasp the professional education on the basis of basic theory, emphasizes the practical application, the key ability to solve practical problems for post area. Which determine the office education teaching practice can be limited in colleges and universities, scientific arrangement for education and equipment to the teaching content, must through various channels, set up as soon as possible to meet the needs of talents growth mechanism of joint training of troops and colleges. To implement joint training troops and colleges, first, to establish equipment practice teaching base. Through the establishment of long-term teaching practice base of equipment, system, into the scale can't be worked as an intern in college practice base for training of new equipment in the force, enhance pertinence and practicability of the teaching practice. Second, to restructure the faculty team as a whole function. Take effective measures to find a way of colleges and universities and interaction with the exchange of cadres' troops as soon as possible the faculty structure by the support degree education to meet the transformation of the position training. Only realize the joint after shaking forces and colleges, to further strengthen the "close to the troops, close to the equipment, and close to guarantee" the teaching idea, the approximate actual combat training and force under the condition of equipment study of teaching practice, training students' ability of serving, improve the comprehensive quality, achieve the teaching goal.

\section{Conclusion}

To strengthen equipment teaching practice is a complicated and meticulous work, we need to continue to explore and practice. Only actively strengthen the practical link in teaching equipment, we will be able to produce popular with the forces of creative ability and work skills, high-quality new military personnel.

\section{References}

[1] Wang Jing-jun, He Xin-peng. Artillery Survey[M]. Beijing: National Defence Industry Press,, 1992.

[2] Tan Le-bin, Zhang Xiang-yan. Artillery Survey[M]. Beijing: Beijing Institute of Technology Press, 2005.

[3] Ma Fu-qiu.etc, Guns and Automatic Weapons[M]. Beijing: Beijing Institute of Technology Press, 2003.

[4] Yan Wen, Tan Bao-lai. the Structure Course of the Groud Artillery[M]. Beijing: National Defence Industry Press, 1995. 
[5] Wang Shu-hai, Gan Lin etc. the Service Course of the Groud Artillery[M]. Beijing: National Defence Industry Press, 2007.

[6] Jeanne L Murtagh. A Freshman Programming Course: Two Chal-lenging Sets of Students, One Solution, Frontiers in Education Conference[A]. FIE'96[C]. 1996. 